\title{
Open Waste Canals as Potential Sources of Antimicrobial Resistance Genes in Aerosols in Urban Kanpur, India
}

\author{
Olivia Ginn, ${ }^{1}$ David Berendes, ${ }^{2}$ Anna Wood, ${ }^{3}$ Aaron Bivins, ${ }^{4}$ Lucas Rocha-Melogno,${ }^{5}$ Marc A. Deshusses, ${ }^{5}$ Sachchida N. Tripathi, ${ }^{6}$ \\ Michael H. Bergin, ${ }^{5}$ and Joe Brown ${ }^{7 *}$ \\ ${ }^{1}$ School of Civil and Environmental Engineering, Georgia Institute of Technology, Atlanta, Georgia; ${ }^{2}$ Division of Foodborne, Waterborne, and \\ Environmental Diseases, National Center for Emerging and Zoonotic Diseases, Centers for Disease Control and Prevention, Atlanta, Georgia; \\ ${ }^{3}$ Department of Epidemiology, Rollins School of Public Health, Emory University, Atlanta, Georgia; ${ }^{4}$ Department of Civil and Environmental \\ Engineering and Earth Science, University of Notre Dame, Notre Dame, Indiana; ${ }^{5}$ Department of Civil and Environmental Engineering, Duke Global \\ Health Institute, Duke University, Durham, North Carolina; ${ }^{6}$ Department of Civil Engineering, Centre for Environmental Science and Engineering, \\ Indian Institute of Technology, Kanpur, India; ${ }^{7}$ Deparment of Environmental Sciences and Engineering, Gillings School of Global Public Health, \\ University of North Carolina, Chapel Hill, North Carolina
}

\begin{abstract}
Understanding the movement of antimicrobial resistance genes (ARGs) in the environment is critical to managing their spread. To assess potential ARG transport through the air via urban bioaerosols in cities with poor sanitation, we quantified ARGs and a mobile integron (MI) in ambient air over periods spanning rainy and dry seasons in Kanpur, India $(n=53)$, where open wastewater canals (OWCs) are prevalent. Gene targets represented major antibiotic groups - tetracyclines (tet $A)$, fluoroquinolines ( $q n r B)$, and beta-lactams (bla $\mathrm{TEM}_{\mathrm{M}}$ - -and a class 1 mobile integron (int/1). Over half of air samples located near, and up to $1 \mathrm{~km}$ from OWCs with fecal contamination $(n=45)$ in Kanpur had detectable targets above the experimentally determined limits of detection (LOD): most commonly int/1 and tetA (56\% and $51 \%$ of samples, respectively), followed by bla $\mathrm{TEM}_{\mathrm{TEM}}(8.9 \%)$ and $q n r B(0 \%)$. ARG and MI densities in these positive air samples ranged from $6.9 \times 10^{1}$ to $5.2 \times 10^{3}$ gene copies $/ \mathrm{m}^{3}$ air. Most $(7 / 8)$ control samples collected $1 \mathrm{~km}$ away from OWCs were negative for any targets. In comparing experimental samples with control samples, we found that int/1 and tet $A$ densities in air are significantly higher $(P=0.04$ and $P=0.01$, respectively, alpha $=0.05)$ near laboratory-confirmed fecal contaminated waters than at the control site. These data suggest increased densities of ARGs and Mls in bioaerosols in urban environments with inadequate sanitation. In such settings, aerosols may play a role in the spread of AR.
\end{abstract}

\section{INTRODUCTION}

Antibiotic resistance $(A R)$ is a growing threat to global public health driven by poor antibiotic stewardship and rapid development and dissemination of resistance in microbial communities as bacteria respond to selective pressure. ${ }^{1-4}$ For example, in 2010, India was the largest consumer of antibiotics and specifically has some of the highest rates of nonprescription use of antibiotics such as carbapenems in addition to minimally funded healthcare and poor sanitation conditions. ${ }^{5,6}$ As a result, studies are finding high prevalence of resistance to carbapenems and other closely related $\beta$-lactam antibiotics. ${ }^{7,8}$ This selective pressure coupled with optimal conditions for bacterial dissemination in the environment may lead to bacterial development of resistance to antimicrobials with genes evolved through random mutations or genes acquired by horizontal gene transfer through the processes of transformation, transduction, or conjugation. ${ }^{9}$ Genes that confer resistance to antimicrobials are known as $A R$ genes (ARGs).

Although most studies have focused on AR development and dissemination in clinical settings, ${ }^{10,11}$ understanding the fate and transport of antimicrobial resistance genes (ARGs) in other settings, including in the ambient environment, is crucial to controlling AR. Studies of ARGs and mobile integrons (MIs) that indicate that genetic transfer has happened or could potentially happen in the environment-including water runoff from animal feedlots; air, soils, and groundwater surrounding wastewater treatment plants; air surrounding poultry farms

*Address correspondence to Joe Brown, Department of Environmental Sciences and Engineering, University of North Carolina, 135 Dauer Dr., Chapel Hill, NC 27599. E-mail: joebrown@unc.edu and markets; and urban environments suffering from severe smog events-indicate prevalent ARGs and high potential for mobility in these environments. ${ }^{2,12-22}$ Some studies have characterized ARGs in ambient urban air where sources are not obvious or widespread fecal contamination is not present. Li et al. ${ }^{20}$ described the global prevalence and relative abundances of 30 different $A R G$ and $M l$ targets in ambient urban air across 19 cities in 13 countries, suggesting widespread presence of ARGs associated with a range of bacterial taxa in cities. However, sources of ARGs in ambient aerosols, absolute densities of specific ARGs of concern, and transport through this pathway as it relates to human exposure remain uncharacterized. Of particular concern are highly contaminated urban areas in low- and middle-income countries (LMICs), where conditions favor AR emergence and transfer; such settings may have widespread environmental contamination, including uncontained fecal waste from people and animals, poor antibiotic stewardship, and high prevalence of pathogens that may acquire resistance to antibiotics. ${ }^{22-24}$ ARG diversity and AR protein concentrations may be effectively reduced when sanitation systems are operating in LMICs, suggesting that fecal waste streams in particular may play an important role in the development and airborne dissemination of resistance. ${ }^{25}$

Because antibiotic-resistant bacteria and ARGs have been measured in bioaerosols near to wastewater treatment plants, ${ }^{13,22,26}$ composting facilities, ${ }^{27}$ and other potential sources where concentrated fecal waste exists, ${ }^{12,15,17,18,28,29}$ we hypothesized that airborne ARGs would be present near uncontained wastewater flows in urban ambient environments where sanitation is poor. We further hypothesized that densities of ARGs in aerosols would be elevated in the dry season when ambient aerosols are relatively higher compared with the rainy season. ${ }^{30}$ 


\section{METHODS}

Study sites and sample collection. We conducted daily aerosol sampling in Kanpur, India, from May to July 2017. Kanpur is densely populated (Nagar district: 4.6 million people, population density of 1,500 persons $/ \mathrm{km}^{2}$ ), ${ }^{31}$ with a majority of untreated industrial, agricultural, and raw sewage waste conveyed via a system of uncovered and uncontained canals open wastewater canals (OWCs) discharging to the Ganges River. ${ }^{32,33}$

Following mapping OWCs across preselected areas in the city, we identified sites meeting the following criteria: 1) proximity to known OWCs ranging from adjacent to up to a 1$\mathrm{km}$ distance, 2) easily accessible, and 3) nonintrusive to residents. We selected a control site greater than $1 \mathrm{~km}$ away from known OWCs and located on IIT-Kanpur's campus. The campus is a controlled private area with limited access to nonstudents and nonfaculty, less densely populated, has underground piped sewerage, and has a much lower animal presence (Figure 1). Kanpur has distinct dry (October to June) and rainy (July to September) seasons. To capture potential seasonal effects, we sampled from May to July to capture periods before and after arrival of the monsoon.

We collected air samples over a period of approximately four hours with the ACD-200 BobCat Dry Filter Air Sampler (InnovaPrep, Drexel, MO, recovery efficiency for $1 \mu \mathrm{m}$ particles is $73 \%{ }^{34}$ ) with $52 \mathrm{~mm}$ electret filters and a flow rate of $150-200 \mathrm{~L}$ per minute, to yield a total sample volume of $36-48 \mathrm{~m}^{3}$ of air per sample. We recorded time of day of sampling (grouped into morning and afternoon) to assess potential diurnal variation of target densities in bioaerosols. To assess OWCs as a potential source, we collected one 45-mL grab sample of wastewater concurrent with aerosol sampling at each of the sites where aerosol samples were taken adjacent to OWCs. Following collection, we transported filters and OWC wastewater samples on ice to the laboratory. We used a single-use wet foam elution kit (InnovaPrep) to elute filters, yielding approximately $6 \mathrm{~mL}$ of liquid eluate for analysis. ${ }^{34}$ In Supplemental Table S1, we include a detailed breakdown of sampling sites, their proximity to OWCs, and how many bioaerosol samples were

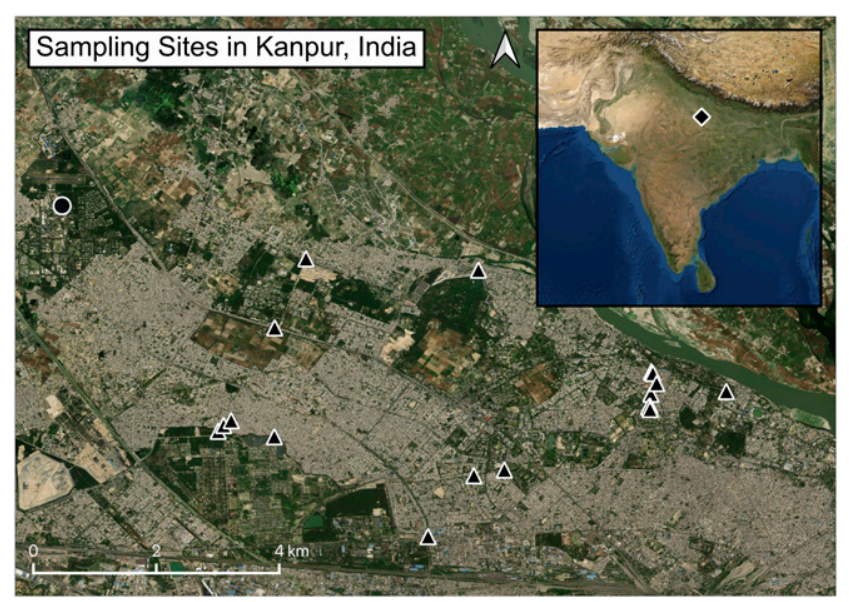

FIGURE 1. Location of sites $<1 \mathrm{~km}$ from open wastewater canals (OWCs) (triangles) and control site $>1 \mathrm{~km}$ from OWCs (circle). This figure appears in color at www.ajtmh.org. taken at each in the dry and rainy seasons. In addition, we include at which sites we collected wastewater samples.

Sample extraction, culture, and analysis. We cultured all aerosol samples to determine the presence of viable Escherichia coli as an indicator of aerosolized fecal waste. Immediately following arrival at the laboratory, we analyzed undiluted air sample eluate and air sample eluate diluted 1:10, and 1:100 via Compact Dry ${ }^{\mathrm{TM}}$ EC plates (Hardy Diagnostics, Santa Maria, CA). ${ }^{35}$ We incubated plates overnight at $37^{\circ} \mathrm{C}$. The limit of detection (LOD) for the culture analysis was determined by dividing one colony-forming unit (CFU, the minimum amount that can be detected on a plate) by the volume of air sampled.

For subsequent molecular analysis, we treated filter eluate and wastewater samples with a guanidine thiocyanate-based universal extraction (UNEX; Microbiologics, St. Cloud, MN) lysis buffer in a 1:1 ratio, stored in SK38 bead tubes (Bertin Corp, MD), and stored all samples at $-80^{\circ} \mathrm{C}$ until extraction. We used $300 \mu \mathrm{L}$ of the sample and UNEX mixture for extraction. After DNA extraction, ${ }^{36}$ we stored extracted nucleic acids in 50-75 $\mu \mathrm{L}$ of $10 \mathrm{mM}$ Tris- $1 \mathrm{mM}$ EDTA $(\mathrm{pH} 8)$ in a $-80^{\circ} \mathrm{C}$ freezer until further analysis. We estimated DNA yield in samples via Qubit ${ }^{T M}$ dsDNA HS (ThermoFisher Scientific, Waltham, MA) and NanoDrop spectrophotometer ${ }^{\mathrm{TM}}$ (ThermoFisher Scientific).

Antibiotic resistance gene and MI quantification. We conducted absolute quantification of ARGs via droplet digital PCR (ddPCR ${ }^{\mathrm{TM}}$, Bio-Rad, Hercules, CA). Reaction mixes were set to a total volume of $20 \mu \mathrm{L}$, containing a primer concentration of $900 \mathrm{nM}$, probe concentration of $250 \mathrm{nM}$, and 1X Supermix for Bio-Rad's QX200TM ddPCR system (Bio-Rad, Hercules). We used the ddPCR ${ }^{\text {TM }}$ Supermix for probes for all targets except bla $\mathrm{TEM}_{\mathrm{TEM}}$, for which we used ddPCR ${ }^{\mathrm{TM}}$ Supermix for Residual DNA Quantification because of the known presence of residual sequence in less purified commercial supermixes. ${ }^{37}$ On each ddPCR ${ }^{\mathrm{TM}}$ plate for all assays, we included two gBlock ${ }^{T M}$ (IDT, Coralville, lowa) positive control wells diluted to approximately $10^{3}$ gene copies $(\mathrm{gc}) / \mu \mathrm{L}$ of the reaction mixture (Table 1). The positive control sequence is also included in a Supplemental File. In addition, we included at least two no template controls using molecular water to control for contamination via human or other error. For two replicates of each sample extract, we quantified gene copies of each target in the ddPCR reaction mixture $(2 \mu \mathrm{L}$ extract, $21 \mu \mathrm{L}$ of ddPCR reagents) and averaged the results together.

Antibiotic resistance gene targets spanned three major antibiotic groups commonly used in low-income settings and whose ARGs have been detected previously in environmental samples-tetracyclines $(\operatorname{tet} A),{ }^{38}$ fluoroquinolones $(q n r B),{ }^{39}$ and $\beta$-lactams $\left(b / a_{\text {TEM }}\right)$. ${ }^{40}$ We also quantified a $\mathrm{MI}(\text { int } / 1)^{41}$ also previously detected in environmental media. Although chosen a priori, a literature review has demonstrated their relevance. Studies have shown that fluoroquinolone resistance has increased in Enterobacteriacea by $7-20 \%$ in just 5 years. ${ }^{6}$ In a pilot study conducted in Vellore, India, $25 \%$ of $E$. coli isolated from urban hospitals $(n=1,075)$ were resistant to tet $A .{ }^{42}$ The bla $a_{\mathrm{TEM}}$ assay used in our analysis represents 135 variants of $\beta$-lactam resistance, including resistance to antibiotics commonly used in the study area such as penicillins, cephalosporins, carbapenems, and other antibiotics that have a $\beta$-lactic ring in their structure. ${ }^{7,8}$ These ARGs therefore capture a wide range of resistance mechanisms and target drugs that are commonly used in sampling locations. ${ }^{40} \mathrm{We}$ 
TABLE 1

Primers, probe positive control sequence, and experimentally determined limit of detection for each assay used in this study to analyze the presence of antimicrobial resistance genes

\begin{tabular}{|c|c|c|c|c|}
\hline Gene target & Primers & Probes & $\begin{array}{l}\text { Limit of detection }(\mathrm{gc} / \mu \mathrm{L} \\
\text { ddPCR reaction mix) }\end{array}$ & Cycling conditions \\
\hline \multirow[t]{2}{*}{ tet $A$} & F: CCGCGCTITGGGTCATT & FAM-TCGGCGAGGATCG-BHQ1 & 0.19 & $\begin{array}{l}95^{\circ} \mathrm{C} \text { for } 10 \text { minutes } \\
45 \text { cycles of } 95^{\circ} \mathrm{C} \text { for } \\
30 \text { seconds and } 56^{\circ} \mathrm{C} \\
\text { for } 1 \text { minute }\end{array}$ \\
\hline & $\begin{array}{l}\text { R: TGGTCGCGTCCCAGTGA } \\
\text { F: CAGATTTYCGCGGCGCAAG }\end{array}$ & FAM-CGCACCTGGTTTGYAG & 0.24 & $\begin{array}{l}98^{\circ} \mathrm{C} \text { for } 10 \text { minutes } \\
95^{\circ} \mathrm{C} \text { for } 10 \text { minutes }\end{array}$ \\
\hline \multirow{2}{*}{ Fluoroquinolines } & & & & $\begin{array}{l}45 \text { cycles of } 95^{\circ} \mathrm{C} \text { for } \\
30 \text { seconds and } 56^{\circ} \mathrm{C} \\
\text { for } 1 \text { minute }\end{array}$ \\
\hline & R: TTCCCACAGCTCRCAYTTTTC & YGCMTATATCAC-BHQ1 & & $98^{\circ} \mathrm{C}$ for 10 minutes \\
\hline \multirow[t]{2}{*}{ bla } & F: CACTATTCTCAGAATGACTTGGT & FAM-CCAGTCACAGAAAAGCATCTTA & 0.12 & $\begin{array}{l}95^{\circ} \mathrm{C} \text { for } 10 \text { minutes } \\
45 \text { cycles of } 95^{\circ} \mathrm{C} \text { for } \\
30 \text { seconds and } 56^{\circ} \mathrm{C} \\
\text { for } 1 \text { minute }\end{array}$ \\
\hline & R: TGCATAATTCTCTTACTGTCATG & CGG-BHQ1 & & $98^{\circ} \mathrm{C}$ for 10 minutes \\
\hline intl1 & F: GCCTTGATGTTACCCGAGAG & 6HEX-ATTCCTGGCCGTGGTTCTGGG & 0.10 & $\begin{array}{l}95^{\circ} \mathrm{C} \text { for } 10 \text { minutes } \\
45 \text { cycles of } 95^{\circ} \mathrm{C} \text { for } \\
30 \text { seconds and } 57^{\circ} \mathrm{C} \\
\text { for } 1 \text { minute }\end{array}$ \\
\hline & R: GATCGGTCGAATGCGTGT & TाTT-BHQ1 & & $98^{\circ} \mathrm{C}$ for 10 minutes \\
\hline Positive control & $\begin{array}{l}\text { ACTTGTCGGACAGGTGCCGGCCGC } \\
\text { GCGACCACGATCGGCATTCGCTTC } \\
\text { AGGATCTGGGTCCAGCGAGCCTTG } \\
\text { CCGCATGGGCACCCATCCAACGGT } \\
\text { TTGGCGTAGCTTAGATTGGTATTCG } \\
\text { ATTCATAAAGCTTGCGCCGCGGAAA } \\
\text { GCATACACTATTCTCAGAATGACTTC } \\
\text { GGCATGACAGTAAGAGAATTATGCA } \\
\text { TGGCAGGCGATATTCATTACTTTG } \\
\text { GTGGCACGAAACCCGCCCTCTGGA } \\
\text { AGTCCGGCTTTGGGTTACACTG } \\
\text { TCGACGGCTCCCCGTGTGCTCATAC } \\
\text { CGCAAAAACCCAGAACCACGGCCA } \\
\text { GGAAGCGCAACGCCGCTGCGGCCC } \\
\text { TGCTCGCGCAGGCTGGGTCCAAG }\end{array}$ & 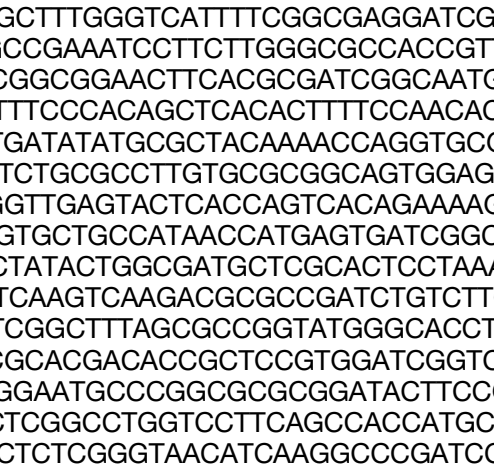 & $\begin{array}{l}\text { CTITCACTGGGAC } \\
\text { TGGCCTTCCTGTAA } \\
\text { GCGCTGACTACGT } \\
\text { GACTITCGAAAAA } \\
\text { 'CGTGGTGATCAT } \\
\text { CAACTCGGTCGCC } \\
\text { CATCTTACGGAT } \\
\text { GAGTTCTTGGGA } \\
\text { ATGCGGGTITCAG } \\
\text { GCCGATCTTCGCG } \\
\text { TCTTCGTCTTCTTC } \\
\text { GAATGCGTGTGCT } \\
\text { GCTCAAGGGCGTC } \\
\text { CCGTGCACGCGAC } \\
\text { 'TTGGAGCCCTTGC }\end{array}$ & \\
\hline
\end{tabular}

processed all samples in duplicate and report means. Reaction mixes, conditions, ARG and MI target sequences, and experimentally determined limits of detection (LODs) for each target are described in Table 1.

We experimentally determined 95\% LODs for each assay using a probit analysis outlined by Stokdyk et al. ${ }^{43,44}$ The $95 \%$ LOD represents the concentration for which the probability of a single ddPCR reaction being positive is $95 \%$. We calculated associations between $\mathrm{ARG}$ and $\mathrm{Ml}$ densities detected in control samples and samples near uncontained fecal waste as well as associations between season and ARG and MI density using nonparametric Wilcoxon tests for non-equal variance based on $95 \%$ confidence (alpha $=0.05$ ). We conducted all statistical analysis in $R$ version 1.1 .383 ( $R$ Foundation for Statistical Computing, Vienna, Austria). ${ }^{45}$

\section{RESULTS AND DISCUSSION}

E. coli in aerosols. Because fecal indicator bacteria can be enriched in aerosols near uncontained fecal waste sites, ${ }^{46-48}$ we hypothesized that culturable $E$. coli would be present in aerosols near OWCs. Of the 45 air samples within the city center of Kanpur and in close proximity to OWCs $(<1 \mathrm{~km})$, $61 \%$ had detectable culturable $E$. coli, with an average density of $0.9 \mathrm{CFU} / \mathrm{m}^{3}$. Control samples taken $>1 \mathrm{~km}$ away from OWCs were negative for culturable $E$. coli (Figure 2, right). Sampling conditions in the Bobcat may have led to an underestimation of $E$. coli: the dry filter and high relative flow rate can limit bacterial survival on capture. We cannot directly link the presence of $E$. coli with ARGs in the present analysis, as ARGs can be carried by a range of bacteria. However, the presence of airborne culturable $E$. coli does confirm aerosolized fecal waste and may indicate the potential presence of resistant phenotypes as observed in a study we conducted with partners in Bolivia. ${ }^{49}$ The finding that $E$. coli is enriched in aerosol samples near OWCs suggests, but cannot unambiguously confirm, that OWC waste may be aerosolized in this setting.

Antibiotic resistance genes and Mls in aerosols. We analyzed 53 air samples for the presence of ARG and MI targets. Seven of eight samples from the control site were negative for ARGs. We analyzed the presence of ARGs and Mls in all samples before and after the 95\% LOD was applied. Targets detected above the LOD represent true positives with 95\% confidence (Table 2).

For two replicates of each sample extract, we quantified gene copies of each target in the ddPCR reaction mixture ( $2 \mu \mathrm{L}$ sample extract, $21 \mu \mathrm{L}$ of ddPCR reagents). Figure 2 (left) shows the mean densities and standard error for each 

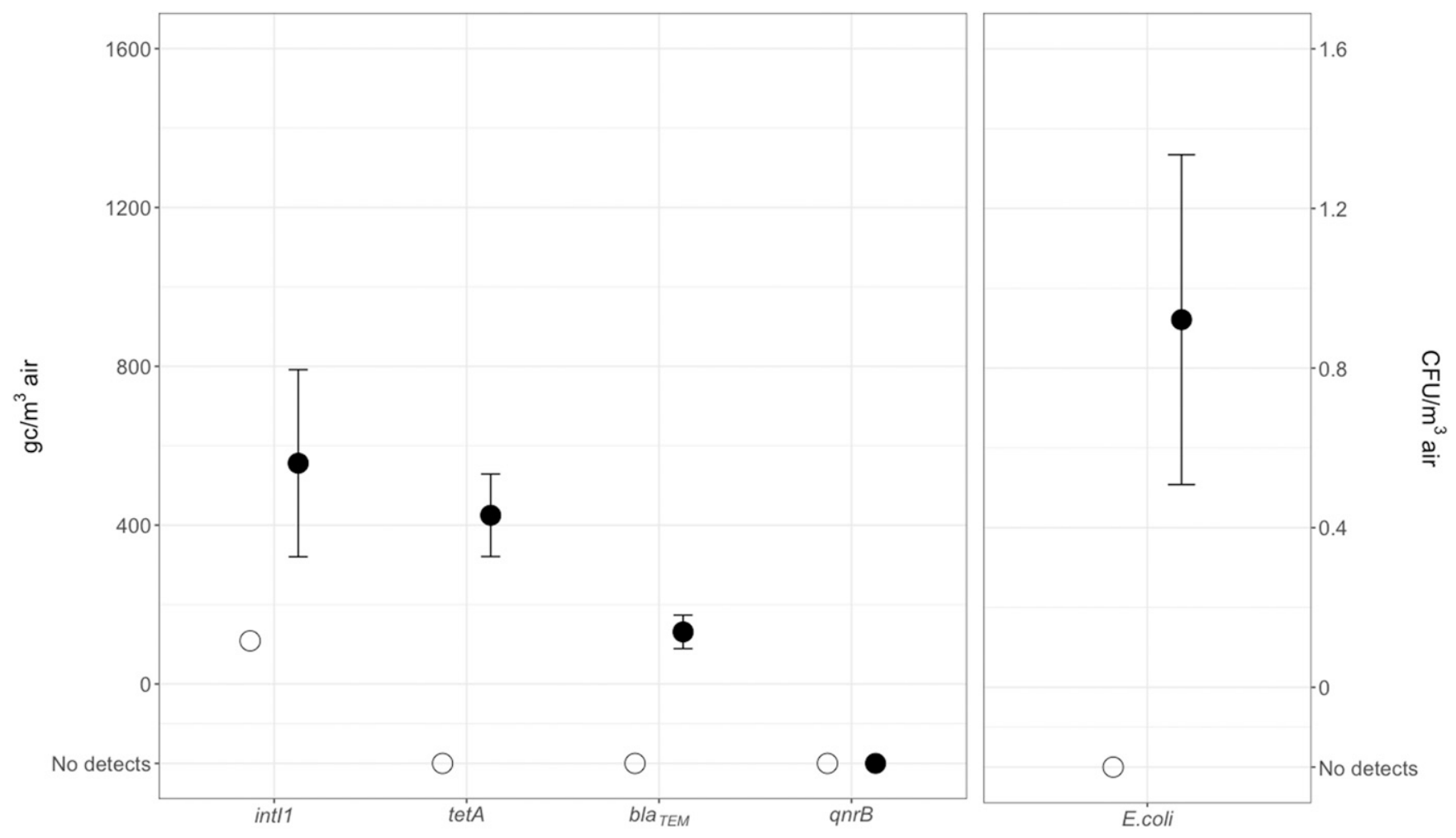

$>1 \mathrm{~km}$ from OWC

$<1 \mathrm{~km}$ from OWC

FIGURE 2. Mean antimicrobial resistance gene and mobile integron densities with mean standard error bars for the distribution in gene copies per cubic meter of air, where targets were detected at levels equal to or above the limits of detection (left). Estimated mean culturable $E$. coli as colonyforming unit per cubic meter of air with mean standard error bars for the distribution (right).

target in samples from each site and the LOD for each target.

We did not detect qnrB in any samples above the LOD at any sites. However, we detected genes encoding resistance to tetracycline $($ tet $A)$, genes encoding resistance to $\beta$-lactams (b/a TEM ), and genes encoding genetic transfer mobility (int/1) above the LODs at all sites $<1 \mathrm{~km}$ from OWCs. One control sample was positive for int/1 above the LOD at a concentration of $108.6 \mathrm{gc} / \mathrm{m}^{3}$. This sample was taken at a height of approximately $10 \mathrm{~m}$ as opposed to the others that were taken at ground level, which may be due to a lack of obstacles at the higher elevated control location. We observed a statistically significant increase in MI and ARG densities in samples $<1 \mathrm{~km}$ away from OWCs compared with the samples $>1 \mathrm{~km}$ from

TABLE 2

Summary of positive detections through ddPCR in all air samples < $1 \mathrm{~km}$ from open wastewater canals before and after leaving the data censored using the 95\% LOD as a conservative threshold for positivity

\begin{tabular}{lcc}
\hline & $\begin{array}{c}\text { ddPCR detections in bioaerosol } \\
\text { samples }(\%, n=45)\end{array}$ & $\begin{array}{c}\text { ddPCR detections in bioaerosol } \\
\text { samples above the experimentally } \\
\text { determined } \operatorname{LOD}(\%, n=45)\end{array}$ \\
\hline intl1 & 73 & 53 \\
qnrB & 2.0 & 0.0 \\
tetA & 71 & 5.0 \\
bla & 24 & 9.0 \\
\hline
\end{tabular}

OWCs for intl1 $(P$-value $=0.038)$ and tetA $(P$-value $=0.012$. $)$ Although we observed an increase in bla TEM density in the samples $<1 \mathrm{~km}$ away from OWCs compared with the samples $>1 \mathrm{~km}$ away, this increase was not significant $(P$-value $=$ 0.4). Other studies in high- and-middle-income countries have reported comparable ARG absolute densities to our ambient outdoor urban samples for specific contaminated sites (e.g., homeless shelters, composting sites, and concentrated animal feeding operations), but urban OWCs are not prevalent where sanitation infrastructure is adequate. ${ }^{27,50}$ Studies reporting relative abundances of ARGs in outdoor ambient air, such as Li et al., ${ }^{20}$ show that a wide range of ARG and $\mathrm{MI}$ subtypes may be detected and that urban air may be enriched with these genes, although sources remain mostly uncharacterized.

In an analysis of the associations between ARG and MI density and season (rainy and dry) (Figure 3), we calculated average densities for each target above the LOD by season. We observed no significant difference between rainy and dry seasons for any target, although we cannot rule out that such differences may exist. Int/1 and tet $A$ appeared to have increased marginally in the rainy season, and bla decreased similarly in the rainy season. Rainfall may decrease the amounts of larger aerosols in the atmosphere, ${ }^{50}$ but our results indicate no strong apparent seasonal trends in this regard related to our targets of interest in this setting. 


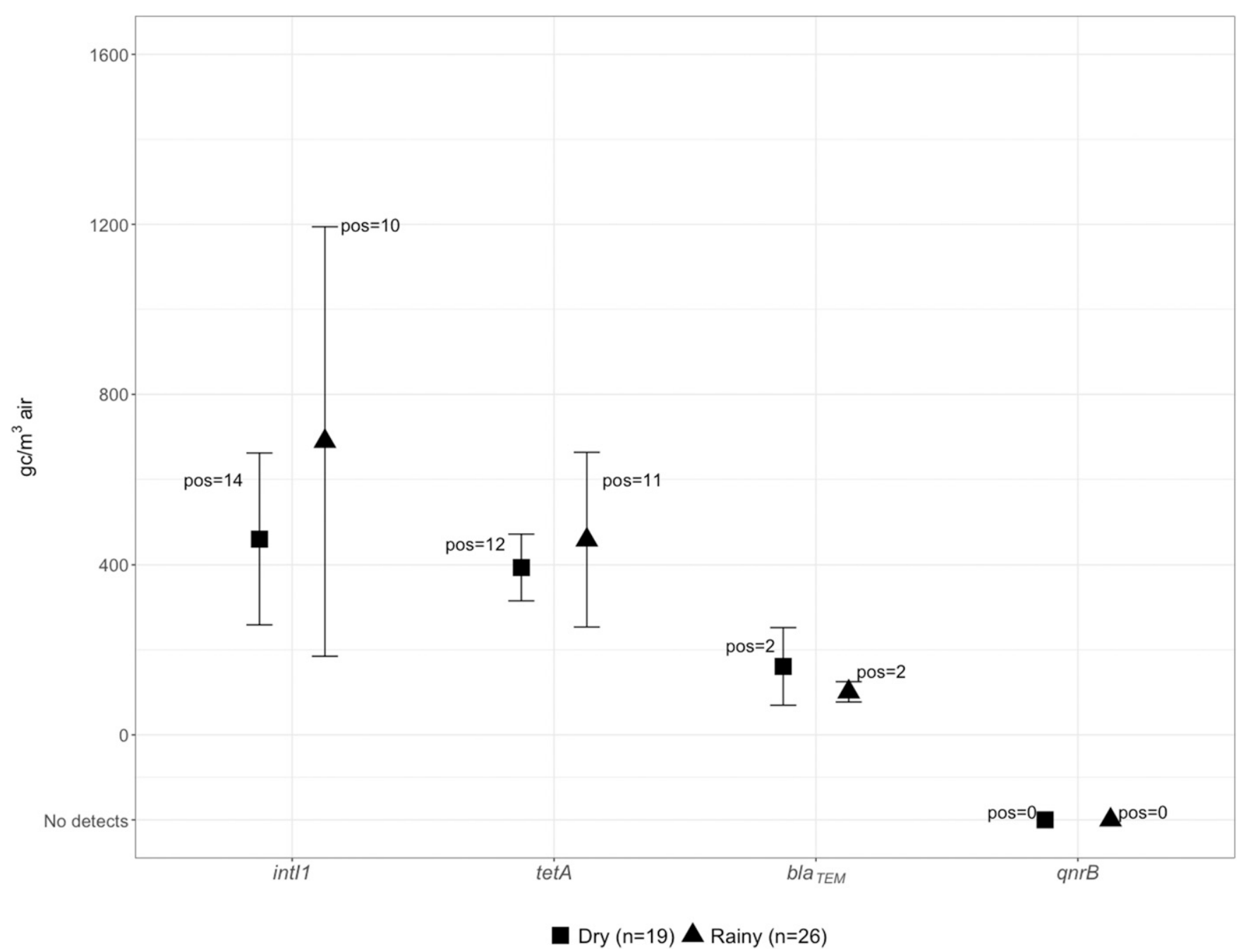

FIGURE 3. Average density of antimicrobial resistance gene and mobile integron targets in gene copies per meter cubed of air sampled. In total, 19 samples were analyzed from the dry season and 26 samples were analyzed from the rainy season. Above each data set for each target, the number of data points that were equal to or above the limits of detection and averaged together for this analysis is displayed.

Open wastewater canal samples. Mean densities of $A R G$ and $\mathrm{MI}$ targets in OWC samples $(n=11)$ were highest for int/1 and tetA $\left(1.8 \times 10^{8} \mathrm{gc} / 100 \mathrm{~mL}\right.$ for both), followed by bla $\left(2.8 \times 10^{6} \mathrm{gc} / 100 \mathrm{~mL}\right)$ and $q n r B\left(1.0 \times 10^{6} \mathrm{gc} / 100 \mathrm{~mL}\right)$. This distribution averaged across OWC samples is consistent with the distribution of average target magnitudes across all aerosol samples, potentially indicating a relationship between the two. Although we collected each OWC sample during a paired aerosol sample, some of the aerosol samples in the pairs were not included in this analysis for a variety of reasons, including instrument malfunction and interference from surroundings. Nevertheless, $6 / 11$ OWC samples have a paired air sample, and a comparison between samples can be found in Supplemental Figure S1.

Open wastewater canal target densities were higher than abundances reported in Chinese surface waters (tet $A$, e.g., ranging from $1.0 \times 10^{5}$ to $5.0 \times 10^{5} \mathrm{gc}$ tet $A / 100 \mathrm{~mL}$ ) but are lower than abundances reported in raw sewage $\left(1.0 \times 10^{10} \mathrm{gc}\right.$ tetA/100 $\mathrm{mL}){ }^{65,66}$ Our results are consistent with previous work implicating wastewaters as sites of concern in the development and dissemination of $A R^{6,53-56}$ For cities with OWCs, direct exposure to this material is possible via flooding or other contact. ${ }^{52}$ Class 1 integrons (int/1) are associated with multiple AR and increased ARG mobility and typically are present in high densities in environments associated with fecal waste. $^{50}$

Open wastewater canals as potential sources. We observed elevated ARG and MI densities at sites near OWCs. With high densities of fecal matter and ARGs in wastewater samples, aerosolization of fecal microorganisms and ARGs is possible, ${ }^{47,57}$ including via mechanical actions such as bubble bursting, ${ }^{57,58}$ rain droplet impacts, ${ }^{50}$ and other phenomena. We further observed that both tet $A$ and intl1, which were detected in OWC samples at substantially higher densities than the other gene targets, were also detected at higher concentrations in the air as well, suggesting a potential quantitative association between density of targets in the OWCs and in nearby air. Although our data strongly suggest that OWCs are a contributing source to aerosolized ARGs in this setting, we cannot rule out other sources that may contribute to elevated ARGs in both matrices. With many possible sources, ARGs could originate from sources like fecally contaminated soils, ${ }^{59}$ animal waste, ${ }^{60}$ and other human activities including composting or solid waste disposal. Future studies could help link 
aerosolized ARGs and specific sources using additional tools of microbial source tracking, aerosol source apportionment, or metagenomics to assess similarity of microbial populations between putative sources and bioaerosols.

Interpretation of our results requires an acknowledgment of the study's fundamental limitations. The number of samples taken prevented inclusion of potentially important covariates, such as time of day of sampling, UV measurements, and other environmental atmospheric data in regression models. In addition, our control site was limited to one location, which may or may not be representative of other areas with similar characteristics. We identified a limited number of ARGs to assess a priori, and despite being of widespread interest in the field, these may or may not have been the most relevant targets for the study setting or for exposure relevance more generally. A wide range of ARGs may be present in ambient urban air, ${ }^{20}$ and they may be attributable to multiple sources and mechanisms of aerosolization, requiring further work to characterize. In addition, although quantification of low gene target densities via ddPCR is improved when compared with quantitative PCR, ${ }^{39}$ concerns of false-positive identification remain and can be a limitation, like any molecular detection method. ${ }^{61}$

Despite these limitations, our results further support the observation that ARGs are present in outdoor ambient air at detectable and quantifiable levels, and that likely sources in our setting of interest are OWCs. To our knowledge, our data are the first to report absolute rather than relative quantification of sanitation-related ARGs in urban aerosols. Density data for ARGs and mobile genetic elements are a necessary first step in the development of risk assessment models that can interrogate their public health relevance, if any, through this pathway. Further work is needed to determine source apportionment and the potential role that aerosols may play in fate and transport of ARGs, and ultimately whether airborne transport is a meaningful pathway in the development and dissemination of AR in highly contaminated environments.

Received September 17, 2020. Accepted for publication January 5, 2021.

Published online March 8, 2021.

Note: Supplemental file appears at www.ajtmh.org.

Acknowledgments: We are thankful for great colleagues at IIT-Kanpur-Hari Shankar, Harish Vishwakarma, Shivshankar Mishraa, and numerous graduate students who helped with instrumentation and shared their laboratory space - and the countless people who shared their homes and their tea with us as we sampled in their community.

Financial support: This material is based on work supported by the National Science Foundation under grant number 1653226.

Disclaimer: The findings and conclusions in this report are those of the authors and do not necessarily represent the official position of the CDC.

Authors' addresses: Olivia Ginn, School of Civil and Environmental Engineering, Georgia Institute of Technology, Atlanta, GA, E-mail: ginnolivia@gmail.com. David Berendes, Division of Foodborne, Waterborne, and Environmental Diseases, National Center for Emerging and Zoonotic Diseases, Centers for Disease Control and Prevention, Atlanta, GA, E-mail: uws8@cdc.gov. Anna Wood, Department of Epidemiology, Rollins School of Public Health, Emory University, Atlanta, GA, E-mail: anna.wood@emory.edu. Aaron Bivins, Department of Civil and Environmental Engineering and Earth Science, University of Notre Dame, Notre Dame, IN, E-mail: abivins@nd.edu. Lucas RochaMelogno, Marc A. Deshusses, and Mike Bergin, Department of Civil and Environmental Engineering, and Duke Global Health Institute, Duke University, Durham, NC, E-mails: lucas.rocha.melogno@duke. edu,marc.deshusses@duke.edu, and michael.bergin@duke.edu.Joe Brown, Deparment of Environmental Sciences and Engineering, Gillings School of Global Public Health, University of North Carolina, Chapel Hill, NC, E-mail: joebrown@unc.edu.

\section{REFERENCES}

1. Vikesland PJ et al., 2017. Toward a comprehensive strategy to mitigate dissemination of environmental sources of antibiotic resistance. Environ Sci Technol 51: 13061-13069.

2. de J, Sosal A, Byarugaba DK, Amabile-Cuevas CF, Hsueh PR, Kariuki S, Okeke IN, eds. 2010. Antimicrobial Resistance in Developing Countries Berling/Heidelberg, Germany: Springer Science and Buisiness Media, 3-36. doi: 10.1007/s13312-0140374-3.

3. Davies J, Davies D, 2010. Origins and evolution of antibiotic resistance. Microbiol Mol Biol Rev 74: 417-433.

4. Pruden A, Pei R, Storteboom H, Carlson KH, 2006. Antibiotic resistance genes as emerging contaminants: studies in northern Colorado. Environ Sci Technol 40: 7445-7450.

5. GARP, 2011. Rationalizing antibiotic use to limit antibiotic resistance in India. Indian J Med Res 134: 3193708.

6. Laxminarayan R, Chaudhuryanan RR, 2016. Antibiotic resistance in India: drivers and opportunities for action. PLoS Med 13: e1001974. doi: 10.1371/journal.pmed.1001974.

7. Shahid M, Singh A, Sobia F, Rashid M, MalikA, Shukla I, Khan HM, 2011. Bla CTX-M, bla TEM, and bla SHV in Enterobacteriaceae from North-Indian tertiary hospital: high occurrence of combination genes. Asian Pac J Trop Med 4: 101-105.

8. Prakash S, 2006. Carbapenem sensitivity profile amongst bacterial isolates from clinical specimens in Kanpur city. Indian $J$ Crit Care Med 10: 10-13.

9. Bennett PM, 2008. Plasmid encoded antibiotic resistance: acquisition and transfer of antibiotic resistance genes in bacteria. Br J Pharmacol 153: 347-357.

10. Schrag SJ, McGee L, Whitney CG, Beall B, Craig AS, Choate ME, Jorgensen JH, Facklam RR, Klugman KP, 2004. Emergence of Streptococcus pneumoniae with very-high-level resistance to penicillin. Antimicrob Agents Chemother 48: 3016-3023.

11. Wellington EMH et al., 2013. The role of the natural environment in the emergence of antibiotic resistance in Gram-negative bacteria. Lancet Infect Dis 13: 155-165.

12. Gao X, Shao M, Luo Y, Dong Y, Ouyang F, Dong W, Li J, 2016. Airborne bacterial contaminations in typical Chinese wet market with live poultry trade. Sci Total Environ 572: 681-687.

13. Li J, Zhou L, Zhang X, Xu C, Dong L, Yao M, 2016. Bioaerosol emissions and detection of airborne antibiotic resistance genes from a wastewater treatment plant. Atmos Environ 124: 404-412.

14. Echeverria-Palencia CM et al., 2017. Disparate antibiotic resistance gene quantities revealed across 4 major cities in California: a survey in drinking water, air, and soil at 24 public parks. ACS Omega 2: 2255-2263.

15. Sancheza HM et al., 2016. Antibiotic resistance in airborne bacteria near conventional and organic beef cattle farms in California, USA. Water Air Soil Pollut: 227-280. doi: 10.1007/ s11270-016-2979-8.

16. Rizzo L, Manaia C, Merlin C, Schwartz T, Dagot C, Ploy MC, Michael I, Fatta-Kassinos D, 2013. Urban wastewater treatment plants as hotspots for antibiotic resistant bacteria and genes spread into the environment: a review. Sci Total Environ 447: 345-360.

17. Liu D et al., 2012. Formation and transmission of Staphylococcus aureus (including MRSA) aerosols carrying antibiotic-resistant genes in a poultry farming environment. Sci Total Environ 426: 139-145.

18. McEachran AD, Blackwell BR, Hanson JD, Wooten KJ, Mayer GD, Cox SB, Smith PN, 2015. Antibiotics, bacteria, and antibiotic resistance genes: aerial transport from cattle feed yards via particulate matter. Environ Health Perspect 123: 337-343.

19. Hu J, Zhao F, Zhang XX, Li K, Li C, Ye L, Li M, 2018. Metagenomic profiling of ARGs in airborne particulate matters during a severe smog event. Sci Total Environ 615: 1332-1340.

20. Li J et al., 2018. Global survey of antibiotic resistance genes in air. Environ Sci Technol 52: 10975-10984. 
21. Zhu YG, Johnson TA, Su JQ, Qiao M, Guo GX, Stedtfeld RD, Hashsham SA, Tiedje JM, 2013. Diverse and abundant antibiotic resistance genes in Chinese swine farms. Proc Natl Acad Sci USA 110: 3435-3440.

22. Zhang M, Zuo J, Yu X, Shi X, Chen L, Li Z, 2017. Quantification of multi-antibiotic resistant opportunistic pathogenic bacteria in bioaerosols in and around a pharmaceutical wastewater treatment plant. J Environ Sci 72: 53-63.

23. Witte $W, 2000$. Selective pressure by antibiotic use in livestock. Int J Antimicrob Agents 16: 19-24.

24. Graham DW, Giesen MJ, Bunce JT, 2018. Strategic approach for prioritising local and regional sanitation interventions for reducing global antibiotic resistance. Water (Switzerland) 11: 27.

25. Pehrsson EC et al., 2016. Interconnected microbiomes and resistomes in low-income human habitats. Nature 533: 212-216.

26. Pal C, Bengtsson-Palme J, Kristiansson E, Larsson DGJ, 2016. The structure and diversity of human, animal and environmental resistomes. Microbiome 4: 54.

27. Gao M, Qiu T, Sun Y, Wang X, 2018. The abundance and diversity of antibiotic resistance genes in the atmospheric environment of composting plants. Environ Int 116: 229-238.

28. Chapin A, Rule A, Gibson K, Buckley T, Schwab K, 2005. Airborne multidrug-resistant bacteria isolated from a concentrated swine feeding operation. Environ Health Perspect 113: 137-142.

29. Gibbs SG, Green CF, Tarwater PM, Mota LC, Mena KD, Scarpino $P V, 2006$. Isolation of antibiotic-resistant bacteria from the air plume downwind of a swine confined or concentrated animal feeding operation. Environ Health Perspect 114: 1032-1037.

30. Hyvärinen AP, Raatikainen T, Brus D, Komppula M, Panwar TS, Hooda RK, Sharma VP, Lihavainen H, 2011. Effect of the summer monsoon on aerosols at two measurement stations in Northern India-Part 1: PM and BC concentrations. Atmos Chem Phys 11: 8271-8282.

31. Kumar P, 2011. Census of India, Series 10 Part XII-A District Census Handbook. Kanpur Nagar, Uttar Pradesh: Directorate of Census Operations.

32. Singh RP, 2001. Effect of wastewater disposal and extent of industrial pollution in and around Kanpur, Uttar Pradesh, India. Bull Eng Geol Environ 60: 31-35.

33. Zia H, Devadas V, 2008. Urban solid waste management in Kanpur: opportunities and perspectives. Habitat Int 32: 58-73.

34. Murowchick P, Alburty D, 2013. Technical Report: Dry Filter Collection/Wet Elution Aspiration and Recovery Testing. Drexel, MO: AlburtyLab, Inc.

35. Kodaka H, Mizuochi S, Teramura H, Nirazuka T, 2006. Comparison of the compact dry EC with the most probably number method (AOAC offical method 96624) for enumeration of Escherichia coli and coliform bacteria in raw meats. J AOAC Int 89: 100-114.

36. Hill V, Narayanan J, Gallen R, Ferdinand K, Cromeans T, Vinjé J, 2015. Development of a nucleic acid extraction procedure for simultaneous recovery of DNA and RNA from diverse microbes in water. Pathogens 4: 335-354.

37. Chiang C, Liu C, Weng L, Wang N, Liaw G, 2005. Presence of $\beta$ -lactamase gene TEM-1 DNA sequence in commercial taq DNA polymerase. J Clin Microbiol 43: 530-532.

38. Guarddon M, Miranda JM, Rodríguez JA, Vázquez BI, Cepeda A, Franco CM, 2011. Real-time polymerase chain reaction for the quantitative detection of tet $A$ and tetB bacterial tetracycline resistance genes in food. Int J Food Microbiol 146: 284-289.

39. Cavé L, Brothier E, Abrouk D, Bouda PS, Hien E, Nazaret S, 2016. Efficiency and sensitivity of the digital droplet PCR for the quantification of antibiotic resistance genes in soils and organic residues. Appl Microbiol Biotechnol 100: 10597-10608.

40. Lachmayr KL, Cavanaugh CM, Kerkhof LJ, DiRienzo AG, Ford TE, 2009. Quantifying nonspecific tem $\beta$-lactamase (blatem) genes in a wastewater stream. Appl Environ Microbiol 75: 203-211.

41. Barraud O, Baclet MC, Denis F, Ploy MC, 2010. Quantitative multiplex real-time PCR for detecting class 1,2 and 3 integrons. $J$ Antimicrob Chemother 65: 1642-1645.

42. Holloway K, Mathai E, Sorensen T, Gray A, 2008. Communitybased surveillance of antimicrobial use and resistance in resource-constrained settings. Anim Genet 39: 561-563.
43. Stokdyk JP, Fimstahl AD, Spencer SK, Burch TR, Borchardt MA, 2016. Determining the $95 \%$ limit of detection for waterborne pathogen analyses from primary concentration to qPCR. Water Res 96: 105-113.

44. Bivins A, Lowry S, Murphy HM, Borchardt M, Coyte R, Labhasetwar P, Brown J, 2020. Waterborne pathogen monitoring in Jaipur, India reveals potential microbial risks of urban groundwater supply. Npj Clean Water 3: 35.

45. RC Team, 2018. A Language and Environment for Statistical Computing. Available at: https://www.r-project.org.

46. Dueker ME, 2012. Connecting Water Quality with Air Quality Through Microbial Aerosols.

47. Cronholm LS, 1980. Potential health hazards from microbial aerosols in densely populated urban regions. Appl Environ Microbiol 39: 6-12.

48. Farling S, Rogers T, Knee JS, Tilley EA, Brown J, Deshusses MA, 2019. Bioaerosol emissions associated with pit latrine emptying operations. Sci Total Environ 648: 1082-1086.

49. Salazar D, Ginn O, Brown J, Soria F, Garvizu C, 2020. Assessment of antibiotic resistant coliforms from bioaerosol samples collected above a sewage-polluted river in La Paz, Bolivia. Int $J$ Hyg Environ Health 228: 113494.

50. Ling AL, Pace NR, Hernandez MT, Lapara TM, 2013. Tetracycline Resistance and Class 1 Integron Genes Associated with Indoor and Outdoor Aerosols. Environmental Science and Technology 47: 4046-4052. doi: 10.1021/es400238g.

51. Heo KJ, Kim HB, Lee BU, 2014. Concentration of environmental fungal and bacterial bioaerosols during the monsoon season. $J$ Aerosol Sci 77: 31-37.

52. WagnerEG, Lanoix JN, 1958. Excreta Disposal for Rural Areas and Small Communities. Geneva, Switzerland: World Health Organization, Monograph Series, No. 39, 1-184.

53. Van Boeckel TP, Gandra S, Ashok A, Caudron Q, Grenfell BT, Levin SA, Laxminarayan R, 2014. Global antibiotic consumption 2000 to 2010: an analysis of national pharmaceutical sales data. Lancet Infect Dis 14: 742-750.

54. Bartley PS, Domitrovic TN, Moretto VT, Santos CS, PonceTerashima R, Reis MG, Barbosa LM, Blanton RE, Bonomo RA, Perez F, 2019. Antibiotic resistance in enterobacteriaceae from surface waters in Urban Brazil highlights the risks of poor sanitation. Am J Trop Med Hyg 100: 1369-1377.

55. Guyomard-Rabenirina S, Dartron C, Falord M, Sadikalay S, Ducat C, Richard V, Breurec S, Gros O, Talarmin A, 2017. Resistance to antimicrobial drugs in different surface waters and wastewaters of Guadeloupe. PLoS One 12: 1-17.

56. Watkinson AJ, Micalizzi GB, Graham GM, Bates JB, Costanzo SD, 2007. Antibiotic-resistant Escherichia coli in wastewaters, surface waters, and oysters from an urban riverine system. Appl Environ Microbiol 73: 5667-5670.

57. Lue-Hing C, Zenz DR, Sedita SJ, 1982. Environmental impact of the microbial aerosol emissions from wastewater treatment plants. Water Science and Technology 14: 289-309.

58. Dueker ME, O'Mullan GD, 2014. Aeration remediation of a polluted waterway increases near-surface coarse and culturable microbial aerosols. Sci Total Environ 478: 184-189.

59. Joung YS, Ge Z, Buie CR, 2017. Bioaerosol generation by raindrops on soil. Nat Commun 8: 1-10.

60. Pillai SD, Ricke SC, 2002. Bioaerosols from municipal and animal wastes: background and contemporary issues. Can JMicrobiol 48: 681-696.

61. Cao Y, Raith MR, Griffith JF, 2015. Droplet digital PCR for simultaneous quantification of general and human-associated fecal indicators for water quality assessment. Water Res 70: 337-349.

62. Zhang T, Zhang M, Zhang X, Fang HH, 2009. Tetracycline resistance genes and tetracycline resistant lactose-fermenting enterobacteriaceae in activated sludge of sewage treatment plants. Environ Sci Technol 43: 3455-3460.

63. Zhang X, Wu B, Zhang Y, Zhang T, Yang L, Fang HHP, Ford T, Cheng S, 2009. Class 1 integronase gene and tetracycline resistance genes tet $A$ and tet $C$ in different water environments of Jiangsu province, China. Ecotoxicology 18: 652-660. 